\section{AIMS IN MEDICINE *}

CHARLES F. STOKES, M.D., LL.D., D.Sc.

Surgeon-General, U. S. Navy

Wasumaton, D. c.
Princeton Paul Crillon Barton was graduated from custom College in the class of 1805 . It was the assume the that time for each member of the class to Barton ado name of some celebrated personage; young initials "p "pted that of Count Paul Crillon, and the He took. C." were retained by him through life.

Pennsylvania degree in medicine at the University of his uncle the class, $\mathrm{D}_{\mathrm{l}}$. Benjamin Smith Barton, graduating in consider of 1808. His thesis on "Nitrous Oxid" was After a classic for many year's.

was appointer internship in the Pennsylvania Hospital, he 1811, just a surgeon in the Navy in 1809. In July, Paul just 100 years ago, the Secretary of the Navy, Mr. plan of orilton, directed Surgeon Burton to outline a presented to said that to Congress for approval. It may be justly ment of Barton was the father of the Medical DepartProf the Navy.

Jefferson Holland, in his admirable history of the 1908 , Medical College of Philadelphia from 182:5 to P.C. states that, in the summer of $1826 \mathrm{Dr}$. William medica Barton was appointed to a new chair of materia cine and and we find later on, when the Burean of Medithe and Surgery was created in the Navy Department, Chief of William P. C. Barton occupying the office of the $N_{\text {avy }}$ Bureau, in reality the first Surgeon-General of Suly.

of his geon Barton published an account of the outlining ment of ther the organization of the Medical Departwere of the $\mathrm{Navy}$, and modestly said that his schemes was permitten together with such order and system as the subject shipblect under the pressure of professional duties on plans was. He stated that the report containing his carelessly certainly less perfectly digested and more demandy treated than the importance of the subject royage because it was written during a tempestuous Horne from Norfolk to New York in the sloop-of-war under, with the ever-to-be lamented Captain Lawrence, mental the disadvantages, too, of seasickness and acute In affiction from the recent loss of a friend.

following teot-note he speaks of his friend Lawrence in the At the mention

ienn, and mention of the name of a man, dear to every Amer. our methose patriotism and valor are deeply registered in impulse of fes, I hope I shall be excused in giving way to an row, I feeling by declaring that, in sickness and in soradministound in this magmanimous hero a comforter who ness; such the sweetest solace with even fominine tenderbigantic and were the superior virtues of a man who was Surgeon valorous in war.

attention Barton was a prolific writer, devoting much

The ded botany in connection with materia medica. istration dedication of his treatise on the internal adminlows:

the Flag Officers, Captrins and Surgeons in the Navy of A Nited States:

ments and rendered glorious by the brilliancy of its achievenity and which has added luster to the nation, given dig. inportance to its character abrond:

of Jeferedictory address delivered before the graduating class erion Medical College, June $5,1011$.
A NAvY-to the seamen of which, by their prowess and their victories, the skilful, the valorous, and the hitherto unconquered naval sons of Britain are forced to yield the palm of superiority:

A Navy-thus eminently distinguished even in infancy, and which has conquered its way to public favor and estimation: This attempt to promote its interests is most respectfully dedicated by the autlior.

In his concluding remarks in this treatise, Dr. Barton has to say the following:

In the foregoing pages I have been necessarily led into the exposition of many and palpable abuses in the Medical Department of the Navy. There are not a few persons with whose interests such an exposition will very much interfere; from them, therefore, I expect no thanks; on the contrary, I look for caviling and censure at their hands. I am, however, prepared to meet it.

My independence in expressing my sentiments on points of duty while in the Navy procured for me not a few enemies; but while I regret this consequence of a line of conduct that thrice the inconvenience could not have made me forego, I have the consoling assurance of having acquitted myself in the way of duty to the entire satisfaction of oflicers with whom I lave served, whose regard and good opinion were of moment. in my estimation.

Both my feelings and my fortune have suffered by the determination I made when I first entered the service, from the execution of which $I$ never in a single instance swerved, to pursue that line of conduct that I deemed consistent with the faithful performance of my duty and my trust, however such conduct might clash with the private or public interests of others, or differ from the customary proceedings of persons similarly situated with myself.

Such were the sentiments of the man who had most to do with formulating the plan of organization of the Medical Department of the Navy and whose name appears in that brilliant and courageous group of original professors who have made possible the great institution of learning from which you graduate to-day.

Your present faculty is built of preciscly the same timber, and in seeking the personification of the highest aims and ideals in medicine I heartily commend their characteristics to your most careful study. I am prond to bring to your notice the close intertwining of the roots of origin that have since grown into the two great medical organizations-Jefferson Medical College and the Medical Department of the Navy.

Since 1842 , when I)r. Barton beeame Surgeon-General, your alma mater has given us mo less than 100 medical officers, and among them are names that have helped to make naval history in the past and are adding further laurels to medicine in the Naval Service to-day. I am proud to tell you that the last commission signed by the President is now in possession of a graduate of Jefferson and a former intern of your hospital.

Is it at all surprising that the mere mention of the name of your great institution of learning should awaken sentiments of affection, esteem and respect in the Navy? I can assure you that the great honor and privilege your board of trustees has conferred on the Medieal Corps in inviting its ranking officer to address you on this occasion, has in nowise lessened this warm spirit of fraternalism.

As you go forth to-day after four years of association in lecture rooms, laboratories, hospitals and elsewhere, eacli inspired with a resolution to solve the problems that lie before him in accordance with the high standards in which you have been so thoroughly drilled, the conviction will be brought home to you that these problems have taken on a new and very personal form calling for the development of a resourcefulness and an indi- 
vidual effort that liad not heen exacted before. Your braring and conduct in meeting these new responsibilities, even at the outset of your careers and in every hour of every day thereafter, will determine largely the measure of success that will be accorded you in the future.

You have chosen the grandest profession of them all, without exception, one demanding courage of the lighest order, sacrifices without end, a profession little appreciated and less materially rewarded for what it has accomplished than any of the others.

It is well for you at this time to endeavor to devclop proper aims and adopt high ideals to guide you in your every-day life, so that the impulse to act squarely and properly to yourselves, your patients and your community will be involuntary and unliesitating.

It has been well said that he is best educated who has the largest and most manageable series of orderly and useful habits in the storehouse of his brain and other nerve-centers. These habits include and cover what are ordinarily understood to be facts as well as reasoning and action. That brain is best equipped which, on the greatest number and variety of occnsions in life, acts in - a fairly automatic manner in the best way for the usefulness and happiness of the individual. Such a personality not only has the highest order of education, but also has the largest development of character in its broadest sense.

In his essay on two kinds of conscience, Norman Bridge has given us much food for thought and a guiding hand in the sclection of high aims in medicine in its relations to individuals and its activities in the community.

He defines conscience as that governing principle, that guide of action, which gives a standard of conduct and judgment to every man. Conscience is largely a matter of education; to some degree it is inborn and, therefore, instinctive; applied to things, beliefs and principles, it is sulsstantially all acquired. In order better to understand the many phases of human conduct, Bridge has described two kinds of conscience; one he has called the personal, or individual, conscience, the other the company, class or collective conscience.

The individual standard is perhaps the higher. It is this conscience that impels man to do what he alone believes to be right. It is the conscience of solitude and tranquillity-of man communing with himself.

The collective, or group, conscience is the standard of the community, and is an altogether different standard from the personal one. The two are often in conffict. although often completely in accord. The feelings and emotions of this standard are in general the ever-present emotions of mankind. All must act outwardly, at least, with slight variations, for the benefit of the race. The collective or group conscience is the executive or official conscience.

It is the personal or individual conscience that tends to impel the soldier, when first under fire, to flee. The group conscience, which has been developed by training and discipline, holds him in ranks with his fellow combatants.

The personal, or individual, conscience has had much to do with the great advances, the epoch-making stands taken by individuals. For instance, Ambroise Paré, the great French surgeon, was ridiculed and called an impostor when he advocated the ligature for arresting hemorrhage, to replace such barbarisms as the routine use of boiling oil and the actual cautery. John Hunter was accused of wasting his time in studying with painstaking care the growth of a deer's horn, but it was this study which led to a knowledge of collateral circulation and emboldened him to ligate the main vessel in anelrism. Harvey spent eight long years of investigation and research before he published his views of the circllation of the blood, which led to lis being discredited, and it was fully a quarter af a century before this estalylished scientific truth became generally recognized.

The difficulties of Jenner were even greater than those of Harvey, and, judging from certain well-menting but misguided efforts that are being made strenuously to-day, not all are yet convinced of the efficacy ${ }^{0}$ raceination against small-pox. The pendulum has swung the other way, and the tendency now is hysterically to grasp the latest thought or idea, claiming vastly more for it than its originator proposed, only to meet with disappointment and discredit, where both are unnecessary.

lt is the group conscience, on the other hand, which rules the mols. A normal development of the two kinds of conscience to meet the vicissitudes of various situna tions leads to the most satisfactory results. In caring for an individual ill, the dictates of the personal conscience should be yielded to; when the welfare of a comp munity is at stake, the promptings of the collective conscience should govern. In a military establishment the individual, or personal, conscience and its promptings are subordinated to the dictates of the group ${ }^{\mathrm{n}}$ science, and this is justified by the objects and aims of such an establishment.

Surgeon Barton's activities and reforms were impelled by a pronounced development of the individual conscience and their beneficent effects are felt to this day.

The internal dissensions and difficulties with which Jefferson College was beset in its early days, as recorded by Professor Holland, resulted from too much persond conscience, and a neglect of the collective standard. With the establishment of a normal balance between the two began a progress almost unparalleled for brilliancy.

Let us see how the cultivation of these two kinds of conscience, in their proper proportions and relations, rill guide us to a wise selection of our aims in medicine. The proper development of the personal conscience will make impossible commercialism, the dividing of fees, and other growing abominations of the day. The welfare of the patient will be our immediate consideration; his personality will receive the close study it merits, and we shall not be treating disease, as such, with the $p^{0 s^{-}}$ sible future applause of the medical society, or the allurements of a statistical report, before us. "We shatl not be wholly engrossed with the laboratory findingsoor

the pathologic report.
Our diagnoses will not be made in the laboratory and in the $x$-ray room. The internist will not be found temporizing and unduly postponing the summoning of the surgeon with the misleading notion that he is practicing conservatism. Often bold, timely operative procedires are of the highest type of conservatism, in that they $\mathrm{m}^{\mathrm{ar}}$ not only save life and safeguard organs that would otherwise have become involved, but they may lead to a restoration of function with a minimum of a ftereffects that delay would have made quite impossible.

The cultivation of that conscience that comes of man communing with himself will lead us faithfully to train every sense with which God has blessed us, to develop manual dexterity, a touch of gentleness with strength and precision that will be recognized at once by our patients. Sight, hearing, smell and taste should not be neglected. Bandaging to-day is almost a lost art; the study of the mechanics of internal medicine and sut 
gery has not received the attention its importance outlet, How often do we find the narrowing of an deformity sluggish muscular wall or an inconsequent of such of the foot, for instance, inducing conditions diable gravity that the slight and often perfectly remeThe mechanical defect is quite lost sight of !

brilliant enormous importance of the laboratory and its and due ereditements in medicine are fully appreciated, have evolved is accorded the courageous minds that stand evolved and demonstrated theories and facts that adrance of as the milestones of real progress in the Among melicine toward the goal of exact science.

adrance is the unfortunate consequences of this great medicine. The dwarfing of the purely clinical side of the diagnosise impulse to turn to the laboratory for findings to the and ufterward to try to fit the laboratory tendency of the individual before us, is undoubtedly the at the be the day. We should center on our patients be, if necide the closest kind of study, and let there laboratory, afty, a tentative diagnosis, turning to the ment ofy, afterward, for a confirmation, or a refinenot well our conclusions. On the other hand, if we are if we found trained clinically we should be quite at a loss reach of the ourselves, perchance, beyond the comforting and thera the liontgen-lay apparatus, and the diagnostic What bearing laboratory.

crowd bearing has the development of the so-called Iet us see. IVitl conscience on our aims in medicine? ling record of 600 ith the growth of this standard the appalcountry to of 600,000 lives sacrificed annually in this comparative preventable discases would soon dwindle into to-day a de insignificance; there would be undoubtedly the cabinepartment of health with a representation in administrat, and the proper institution of sanitary nities the bive methods would yield in our civil commuods whe brilliant results that have followed these methhave been the medical officers of the Army and Navy sibly only permitted to carry them out, hampered posof the situritionsucicient funds, or the military features It is mation.

will be more than probable that this crowd conscience tance to developed, as it should be, only when its imporlars-and-cent masses is browght home to them on a dolor collectits basis. The lack of the so-called executive only amarive conscience in these United States is not country haz-it is appalling. The fact that this great of Hygien no exhibit at the International Exposition fitting for , in Dresden, now in session, is verhaps not You her me to comment on.

and that young men say that medicine is overcrowded little left so much has been accomplished that there is coveries, or be done. Should there be no further dison, and we advances, in melicine and surgery from now the facts were permitted to make use intelligently of medicine, now in hand, the achievements of preventive conservatisministrative sanitation and bold surgieal

The erim would startle the world.

criminal coumes of commission that find their way to our with the courts sink into insignificance when compared ing, direfrave crimes of omission and their far-reachference, take consequences which we, in hardened indifuntouched as a matter of course. Here is an almost an awaken field. Results can come only, however, from tion, teaming of the crowd conscience through educaAn example and convincing demonstration.

conscience of eties and is seen in the boards of trustees, guilds, socipitals and organizations that make possible our great hosand educational institutions. These splendid citi- zens often contribute liberally in a financial way and bring to bear their business training and administrative ability, to say nothing of time and painstaking labor, in this field of work. They should share with us the honors that may come to us, for they have made possible what measure of success may be ours.

President Taft showed thorough appreciation of this most excellent type of citizen when he eulogized recently the man who contributed to the revolutionary cause, without hope of reimbursement, $\$ 650,000-$ an enormous fortune for those days. Such as he made the success of our arms possible, and great sacrifices of this sort merit recognition along with the actual achievements of war. Those who by their sagacious activities awaken and keep alive intelligent putriotism, thus making possible an approach to preparedness when the horizon is not darkened by war-clouds, should be classed with the great leaders of peace times. The pseudo-patriotism and hysterical outbreaks that often come with the declaration of war are out of time and out of tune, and while ostensibly well meaning, are of little account.

The activities of physicians in civil life are almost entirely along humanitarian lines, while in the Army and Navy humanitarian considerations are of secondary importance, military duties being paramount. To understand properly the necessity for this subordination of the humanitarian aims of medicine, it will be well to outline some of the unusual features of the fighting establishments, and the Navy will serve admirably for the purpose.

The Navy is manned, equipped, organized and maintained to fight. The fleet is the Navy. The development of the highest type of fighting efficiency in the flect should be the aim of all concerned. This problem is decidedly more intricate and difficult than is generally realized, both inside and outside the scrvice. The battles of the future will no longer be the battles of brawn; they will be the battles of brains and they will be won by the combatant showing the highest development along this line. Science has taken a hand, and in the front rank we find specialized medicine, chemistry, mathematics, mechanics, physics and many scientific offshoots so harnessed, adapted and molded as to make possible a grade of military efficiency that was scarcely dreamt of a decade ago. Consider for a moment what the development of electricity has accomplished; what chemistry has contributed in the way of powder alone; what oil as fuel will do!

Each new activity brings to bear on the personnel new influences often seriously damaging to efficiency. It is of the greatest military importance that the medical department should not only familiarize itself with these scientific specialties and be prepared to repair the damage to the personnel from their employment in the fleet, but what is stil] more important, it must prevent and actually is averting this damage.

Side by side stand the lieutenant and the surgeon; the one by drilling and discipline striving to attain a high grade of efficiency, the other, who has selected at the recruiting station the physical type best fitted to meet the peculiar requirements, watches intently for effects that are likely to impair efficiency. For example, recently, on an endurance run, thirty odd men, utterly prostrated, were carried out of the fire room of a ship.

What was the cause of this serious breakdown in the personnel? Was it due to excessive heat, to contaminated air, to improper food or water? Or was it due to the assignment to duty in the fire room of a type physically unsuited to the arduous exactions of that 
station? These are the questions that would naturally come to the mind of an alert medical officer, and it is along these lines that the Bureau of Medicine and Surgery is bettering conditions.

The activities of the medical department are by no means confined to the personnel. The plans of new ships are always referred to the Surgeon-General before they are finally approved by the Navy Department. It is his duty to give them careful study, recommending such changes as in his opinion will keep the physical make-np of the personnel at the highest piteh, and at the same time will in no way impair the fighting possibilities of the ship. These recommendations are not in any sense prompted by humanitarian considerations; they are made solely to promote and maintain military efficiency.

What is the character of the personnel with which we have to deal? Let us consider two types of officers, the two whose duties and responsibilities are more closely allied than any of the others-line officers and medical officer's.

The line is recruited from all over the country, from practically every grade of society, who, after passing rigid professional and physical examinations. begin a four years' technical course at the Naval Academy with an additional two years spent at sea, before they are finally commissioned. During the four years at Annapolis, the highest aims of their profession are instilled into them, such as discipline, honorable dealing, manliness, pliysical and moral courage, a proper conception of duty and its responsibilities, loyalty and patriotism and a willingness unhesitatingly to make that greatest of all sacrifices for their country's sake should occasion demand it. This splendid spirit was highly developed in that superb soldier, the late Captain Capron of the Aruny, who, on hearing that his son, a Rough Rider, had been wounded during the battle of San Juan Hill, in which both had been engaged, sought him out to find him lying dead at the roadside. Brushing back the hair from his brow, he scanned the features, strong even in death, and said. patting him affectionately on the head, "Well done, old fellow."

The development of this splendid spirit is by no means confined to the line; it underlies and guides the activities of the entire commissioned and enlisted personnel of the Navy.

The Medical Corps is the only branch of the service which may select jts own personnel. Not only must a candidate be a graduate in medicine, but he is required to have served in a great civil hospital and present a diploma as a guarantee of the churacter of this service, before he is eligible to examination for a commission as assistant surgeon. $\Lambda \mathrm{n}$ examining board then passes on his physical and professional qualifications, and if he meets the requirements, he is commissioned and enters the Naval Medical School, where he is taught the military features of his duties and is given special training to fit lim for the great responsibilities of his new career. $\mathrm{He}$ is required to pass still another examination on the completion of this course, when he is assigned to the flect for duty.

To have the right to wear the uniform of the United States Navy to-day is one of the greatest honors that can come to any of us, and that uniform which bears the insignia of the Medical Corps, with all it implics, is without a peer in the service. It is hoped that yon will carefully consider these facts in choosing your life work in medicine.
And what of the enlisted personnel? With the pas. sage of masts, spars, sails and wooden ships went much of the romance of the sea, and along with the rest that faithful, resourceful type, the old-time sailorman. He is but a memory to-day, having been replaced by the alert young seaman-mechanic. The pace, with its $\mathrm{com}^{\mathrm{m}}$ plicated responsibilities, became too fast for the old fellows, and they have dropped out of the race com pletely.

In the Atlantic Fleet on its round-the-world crivise the average age of the enlisted personnel was about twenty one years, on hearing which some humorist remarked that the Navy was manned by boy's.

In order better to understand this new-type seamanmechanic, let us look into a turret and see him actually at work. There are inmumerable other situations in the complex make-up of a battleship that might be selected, still the turret will perhaps serve our purpose as well as any.

Side by side within this armored citadel lie the breeches of two monster 14-inch guns. The guns with their crews are separated by an incomplete partition of bulkhead, thereby stimulating a spirit of rivalry between the two gun-crews. There we see the turret officer, the turret captain, the gun-pointers and the crews. Gold lace has given way to dungarees; the cap alone dis. tinguishes the commissioned officer-the men are nude to the waist. Each man is at his station, forming an unbroken chain from the gun to the magazine below with its tons of powder and shell.

The range of these guns is some .14 miles; the $\mathrm{pr}^{0}$ jectile, propelled by the burning of 350 pounds of powder, weighs $3 / 4$ of a ton, costing about $\$ 500$ for single discharge. The monster blast is likely to destroy all unprotected ear-drums within a given zone, at the same time liberating gases poisonous in the extreme, so much so that, in one ship in which artificial rentilation was maintained during battle, several men were found unconscious in a single compartment into which the blowers had driven these noxions fumes.

From the fighting top comes a message to the central station in the bowels of the ship; a calculation is hastily made and directions are sent out to the turrets. The guns are trained accordingly; the gun-pointer picks up the enemy with his telescopic sight; the cross-wires are on him, the order to fire rings ont, the gun is discharged and mathematically there should be a hit. We have, however, a personal element to take into consideration.

The picture is inspiring. The perfect team-work, the silence, the earnestness of great purpose written on ench face strikes even the casual observer. The hazards of the situation are fully appreciated by all, yet the very dangers tempt those of the proper make-up for a fighting organization to seek these assignments. By constant drilling, mutual dependence, and perfected discipline the chances of mishap become very small; yet one weak link in the chain may instantly hurl all into eternity and perhaps destroy the ship.

What part does the medical officer play in all this? It is his duty to weed out the physical weaklings, or build them up, to safeguard these picked men from disease, to eliminate those whose nervous make-ups unfit them for this kind of duty; in other words, he has before him not only a study of the gross physical features of the personnel, but their psychologic characteristics as well. Let IIs center on the gun-pointer. If this man is of a highstrung nervous type, or has "too much" education, it lias been found that, when the cross-wires of his telescopic 
sight are on the target, his alert mind is centered on the. his sides of the ignition of 350 pounds of powder at personal and the chance for a hit has slipped by. . His crowd conscience has failed to be subordinated to his has been foucence as it should be in this situation. It has in found that the use of telescopic sights at dills these many instances seriously impaired the vision of and is ren. 'This break in the chain is of serious moment 'The constring the careful study its importance merits. high speed tructors may give us stability, the engineers command, the ordnance officers effective rifles and the the ounders maneuver with consummate skill, still if have hitsointers camnot see straight we are not going to defert

It is believed that the next naval battle between power's that first class will last less than thirty minutes. By probably either the one or the other combatant will exhausted. destructive. The wounds of naval warfare are peculiarly outright_-acerating tissues, splintering bones, killing tically all and are attended with profound shock; pracof the all are infected from the start. What are the aims be militaryed department during battle? They should greatly absolutely; humanitarian activities, although mighty to be desired, have no place in this situation, failure of lead to additional casualties and possibly the At of our arms.

departme close of battle the activities of the medical efforts art at once become humanitarian, and our wounded often exerted, not only in behalf of our own At this but in behalf of those of the enemy as well. and milit point the heretofore diverging paths of civil ground mitary medicine are reunited on humanitarian Our militer the beneficent influences of the red cross. results military efforts may lead to broad humanitarian fewer in making victory more decisive, thus entailing been warred ties, and, further, the war itself may have with waged by reason of inhmmanities which would cease prisone success of our arms. The humane treatment of after hostilients of war by medical officers, before and lishing filities have ceased, is a potent factor in reestabCon friendly relations afterward.

tures of thation in the past on the purely military fea-

a neglect fleet has led to a one-sided development with

have in of the humanities of naval warfare that would

ment, the possible a breakdown in the medical depart-

I he most appalling in history.

ment of devised a plan which will, with the establishattend the Naval Medical Reserve Corps, efficiently which to all our humanitarian responsibilities, and larfare, fair to revolutionize this feature of naval gical care, giving to the wounded the highest type of surposed of from the firing-line until they are finally diswork that and this they surely merit; it is in this field of loguthat I sliall one day turn to you, my respected colIn ador support.

medicine adion to the complex responsibilities of naval are the dutilined, I fear, at too great length already, precisely thes that go with service in the ficld which are are natural same as those of the Army, except that they war in rally not quite so extensive. There has been no world recent times, however, in which the navies of the The proper taken part in operations on shore.

farious action equipment and execution of these multisupply activities have led to the establishment of great there are ots, hospital and supply ships and the like; medical dever 2,000 individuals serving in and under the

A word in conclusion as to what is clone along humani. tarian lines. Fach ship has its sick-bay which may be likened to an army post hospital, and there are some fifty old ships in commission.

The hospital ship Solace, equipped with 200 beds, with facilities equaling those of your metropolitan hospitals and carrying a number of skilled specialists, is serving with the Atlantic Fleet. There are nineteen general hospitals in commission, some of them among the largest and best equipped in the country, with six more building, constituting one of the largest hospital organizations in the world. We attend as well the large body of civil employees at navy vards and stations and the inlabitants of our island and outlying possessions. In this humanitarian field of work our aims and activities are precisely the same as those of civil practitioners, with the adiled interest of service in Alaska, Japan and the tropies.

From what has been said it is plain to be seen that in the Navy certainly the per'sonal conscience must be subordinated to the collective conscience, and humanitarian aims give way to the military, up to a given point, at least. The medico-military duties referred to necessitate a profound study of all activities connected with naval warfare, in order to implant in the service, intelligently and effectively, what scientific melicine, in all its ramifieations, has to offer to enbance militury efficiency. It gives me great pleasure to express my unqualified appreciation and gratitude to the many skilled specialists in civil life, and, partieularly, to the Faculty of Jefferson Medical College, for the painstaking, patriotic assistance they have unfailingly given us in our efforts to accomplish this great work.

If a single individual within hearing of my voice, or elsewhere, is helped in the choice of his aims and ideals in medicine, or in any other calling-if he is aided in any measure to the development of such a proportion between his individual conseience and his collective conscience as to lead to personal success and broadened public service in the community in which he resides, I shall feel fully recompensed for the effort that has been made.

\section{SOME TENDENCIES IN MEDICAL EDUCA- TION IN THE UNITED STATES *}

LEWELLYS F. BARKER, M.D.

Professor of Mediclne In Johns Ilopkins Unlversity and I'hysiclan. in-Chief to Johns Hopkins Hospltal IBAITIMONE

THE PASSING OF THE INFERIOR MEDICAL SCHOOLS

If you compare medical education in the United States twenty years ago with what it is to-day, you cannot help but be impressed with the romarkable change which has taken place. The period has witnessed a reform which is noteworthy in history. During the past decade, especially, there has been a steady decrease in the number of inferior medical schools and an elevation of standards in the better schools. The country has passed rapidly from a stage in which the proprietary. medical school was dominant to one in which all, or nearly all, of the better medical schools are the medical departments of universities.

* Based on remarks made at the convocation exerclses at MeGill Unlversity, Montreal, June h, 1911.

* Owing to the lack of space this paper has been reduced nearly half. The unabridged artlcle is pilinted in pumphlet form and wijl lo sent by the author, or by THE Joursil, on receipt of a staniped directed envelope. 